\title{
Particle Diameter and Nutrient Related Studies of Anaerobic Biodegradation of Lignocellulose from Corn Stalks in Biogas Production for Sustainable Energy Development
}

\author{
Anthonia Eseyin ${ }^{1}$, Kieran I. Ekpenyong ${ }^{2}$, Onyanobi Abel-Anyebe ${ }^{3} \&$ Dinesh Mohan $^{4}$ \\ ${ }^{1}$ Department of Remedial Sciences, University of Jos. Plateau State, Nigeria \\ ${ }^{2}$ Department of Chemistry, University of Jos. Plateau State, Nigeria \\ ${ }^{3}$ Science Laboratory Technology Department, Benue State Polytechnic, Ugbokolo, Nigeria \\ ${ }^{4}$ School of Environmental Sciences, Jawaharlal Nehru University, New Delhi, India \\ Correspondence: Onyanobi Abel-Anyebe, Science Laboratory Technology Department, Benue State Polytechnic, \\ Ugbokolo, Nigeria. Tel: 234-706-494-8786. E-mail: onyanobi@yahoo.com
}

\author{
Received: November 27, 2012 Accepted: August 12, 2013 Online Published: September 29, 2013 \\ doi:10.5539/ijc.v5n4p66 \\ URL: http://dx.doi.org/10.5539/ijc.v5n4p66
}

\begin{abstract}
Unextracted lignocellulose from corn stalks was investigated for its anaerobic biodegradability at $38{ }^{\circ} \mathrm{C}$ using mixed micro organisms harnessed directly from the air. The effects of particle diameter and certain nutrients on biodegradability were investigated. The highest biogas yield was observed for $\leq 1.0 \mathrm{~mm}$ particle diameter size, followed by $\leq 2.0 \mathrm{~mm}$ particle diameter and then $\leq 3.0 \mathrm{~mm}$ particle diameter. Potato dextrose agar (PDA) and urea were found to increase biogas yield when in low concentrations. The combination of PDA and urea in low concentrations is a better nutrient than either PDA or urea alone.
\end{abstract}

Keywords: lignocellulose, biomass, biogas, anaerobic degradation, particle diameter, biodegradability, corn stalks, digester

\section{Introduction}

Various sources of energy have been used by man over the centuries in order to meet his basic life needs like food, shelter and water. Man started by using his own energy and sunlight after which he progressed to wood, coal, draft-animal power, fossil fuel and nuclear energy. In essence, man has utilized energy in modifying and manipulating land, water, plants and animals to obtain food, clothing and shelter.

Before the discovery of inexpensive fossil fuels, our society was dependent on plant biomass to meet its energy demand. The discovery of crude oil, in the $19^{\text {th }}$ century created an inexpensive liquid fuel source that helped industrialize the world and improved standard of living. The petroleum resources are declining and inadequate for emerging economies, also, there are political and environmental concerns about fossil fuel. It is therefore now imperative to develop and utilize economical and energy-efficient processes for the sustainable production of fuels and chemicals to supplement the available commercial energy sources. In this regard, plant biomass is the only current sustainable source of organic carbon (Klass, 1998, 2004; Wyman et al., 2005).

Biogas refers to the gas produced by the breakdown of organic matter in the absence of oxygen and it is a renewable energy source. In the past decade, research and development have been intensified on a wide range of the energy technology options available. Experimental results on a pilot plant have been encouraging. The merits of the biogas technology for rural energy needs have been evaluated with regard to energy requirements, capital cost and receptivity of the people. Biogas technology has been developed to convert biomass to useful energy without destroying the fertilizing properties of wastes. The biogas generated can be used to supply energy for domestic cooking and lighting, space and water heating and refrigeration. It can also be used as fuel for automobiles motive power, electricity generation and mechanical energy (Ajiboye, 1994).

Due to lack of commercial energy supplies in rural areas, biomass energy formations such as straw, stalks and fuel wood are primarily the energy sources for daily cooking and domestic heating ( $\mathrm{Li}$, Zhuang, Pat, \& Larson, 2001; Zeng, Y. Ma, \& L. Ma, 2007). Direct combustion of biomass causes serious environmental degradation problems like indoor air pollution (Smith, 1994), deforestation (Zeng et al., 2007) and superfluous emissions of 
volumes of greenhouse gas (Streets \& Waldhoff, 1999; Bhattacharya, Abdul-Salam, \& Sharma, 2000). Furthermore, there is also, wastage of large quantities of energy due to low utilization through incomplete combustion in the fire stoves (Smith, 1994).

There is therefore an increase in international interest for the development of low carbon renewable energy technologies. Biogas is a robust fuel that can supply heat and electricity; it can also be used to process steam and methanol. (Jingura \& Matengaifa, 2009). When biofuels are compared generally, biogas turns out to be one of the most interesting because, the cultivation of specific crops like rapeseed is required in the production of biodiesel whereas, biogas can be produced from manure and agricultural wastes. Also, all components of a biomass substrate can be anaerobically digested unlike in biodiesel production where only lipid components can be used (Börjesson \& Mattiasson, 2008).

Biogas, being a clean, efficient and renewable source of energy, has been officially popularized as a substitute for other fuels for the purpose of energy savings and environmental protection in rural areas. Various approaches have been developed for the treatment and elimination of organic wastes that often involve biological systems. (Ahring, 2003; Pind, Angelidaki, \& Ahring, 2003). Obviously, the production and utilization of biogas can effectively reduce the fuel consumption of rural families by partly replacing coal, oil, fuel, wood, straw, stalks, livestock manure, etc. (Wang \& Li, 2005; Wang, Di, Hu, Wu, X. Jiang, \& S. Jiang, 2007; Li, Tang, Xia, Luo, \& Zhong, 2005).

Biogas is a colorless flammable gas obtained by the anaerobic digestion of plant -based organic waste materials like straw, corn stalk, human waste, livestock manure and organic waste mixtures in household anaerobic fermentation digesters. Biogas has the following composition: -methane 50-70\%, carbon dioxide 30-40\% nitrogen $0-10 \%$, hydrogen $0-1 \%$, hydrogen sulphide $0-3 \%$, oxygen $0 \%$ depending on the origin of the anaerobic process (Bhattacharya, Thomas, \& Abdul-Salam, 1997; Zhang et al., 2007).

Like natural gas, biogas can be compressed and used to power motor vehicles, where it can fuel internal combustion engines or fuel cells. In the UK, for example, biogas is estimated to have the potential of replacing about $17 \%$ of vehicle fuel (Calverton Energy Conference). Biogas can be cleaned and upgraded to natural gas standards.

1) Anaerobic decomposition can be described as a two stage process. In the first stage, acidic bacteria decompose the complex organic molecules into simpler compounds like peptides, glycerol, alcohol and the simple sugars. When these compounds have been produced sufficiently, a second type of bacteria starts to convert these simpler compounds into methane (www.habmigern2003.info/biogas/methane).

2) Anaerobic decomposition takes place at temperatures between $0{ }^{\circ} \mathrm{C}$ and $69{ }^{\circ} \mathrm{C}$. However, the action of the digesting bacteria decreases sharply at temperatures below $16^{\circ} \mathrm{C}$. Gas production is most rapid between $29{ }^{\circ} \mathrm{C}$ and $41{ }^{\circ} \mathrm{C}$ or between $49{ }^{\circ} \mathrm{C}$ and $60^{\circ} \mathrm{C}$. This is because the two different types of bacteria multiply best at these two different temperature ranges (www.habmigern2003.info/biogas/methane).

This paper examines the anaerobic biodegradability of corn stalks at $38{ }^{\circ} \mathrm{C}$ using mixed micro organisms harnessed directly from the air. It also examines the effects of three different mesh sizes on the biodegradability of corn stalks. Furthermore, the additions of certain nutrients like potato dextrose agar and urea, used individually and also in combination and their effects on biogas production are examined.

\section{Experimental}

\subsection{Preparation of Crushed Corn Stalks}

Dry corn stalks were collected from a farm in Jos, Plateau state Nigeria and dried in a 330 Gallenkamp (England) oven at a temperature of $105{ }^{\circ} \mathrm{C}$ for 24 hours to eliminate moisture. The stalks were further cut into smaller pieces and crushed in a Morris Jar Mill. The crushed stalks were then sieved into $\leq 1.0 \mathrm{~mm} ; \leq 2.0 \mathrm{~mm}$ and $\leq 3.0$ $\mathrm{mm}$ particle diameters using Endicott's Lab Test Sieves. These samples were then pre-exposed to ambient laboratory air for $24 \mathrm{hrs.} 4.0 \mathrm{~g}$ of each sample was then used in preparing slurries for the biodegradation carried out under varied conditions. Each biodegradation was carried out twice, after which the average biogas volumes produced were determined and recorded. The biogas volumes produced were collected over water at room temperature in a research laboratory at University of Jos.

\subsection{Preparation of Potato Dextrose Agar (PDA)}

Old Irish potatoes were purchased from an open market in Jos, $333 \mathrm{~g}$ of the potatoes were washed, peeled, finely diced, then boiled gently for 30 minutes. After boiling, they were strained with a cheese cloth squeezing out all liquid. The boiled and strained diced potatoes were placed in $1000 \mathrm{~cm}^{3}$ deionized water, to which $25 \mathrm{~g}$ dextrose 
and $20 \mathrm{~g}$ agar had been added. The mixture was boiled to dissolve the dextrose and agar. $8 \mathrm{~cm}^{3}$ of the mixture was dispensed into screw capped tubes and autoclaved at $121{ }^{\circ} \mathrm{C}$ and $15 \mathrm{lb}$ pressure for 15 minutes. The PDA was cooled in slanted position. Another $8 \mathrm{~cm}^{3}$ was dispensed into screw capped tubes and autoclaved for another 15 minutes. The final $\mathrm{pH}$ was found to be 5.6.

\subsection{The Biogas Digester}

Anaerobic digestion experiments were carried out in a laboratory of $32{ }^{\circ} \mathrm{C}$ room temperature, in a hot water bath of $38{ }^{\circ} \mathrm{C}$. The biogas anaerobic digester comprised of two $100 \mathrm{~cm}^{3}$ Quick fit round bottomed flasks held by clamps fitted on retort stands. The digester was fitted with rubber corks and placed in a Techne (England) water bath equipped with regulated heating/stirrer coil. The digester was then connected via rubber and glass delivery tubes to burettes which were filled with water and placed in an inverted position inside a water trough. The water bath was filled with water and the regulator set at $38{ }^{\circ} \mathrm{C}$. A thermometer was placed in the water bath to monitor the temperature of the digester. Biogas was collected through a water displacement system in burettes. Each biodegradation was carried out twice under the same conditions after which, the average biogas volumes produced were determined and recorded. However, the constructed digester was unable to accommodate more than two flasks at the same time.

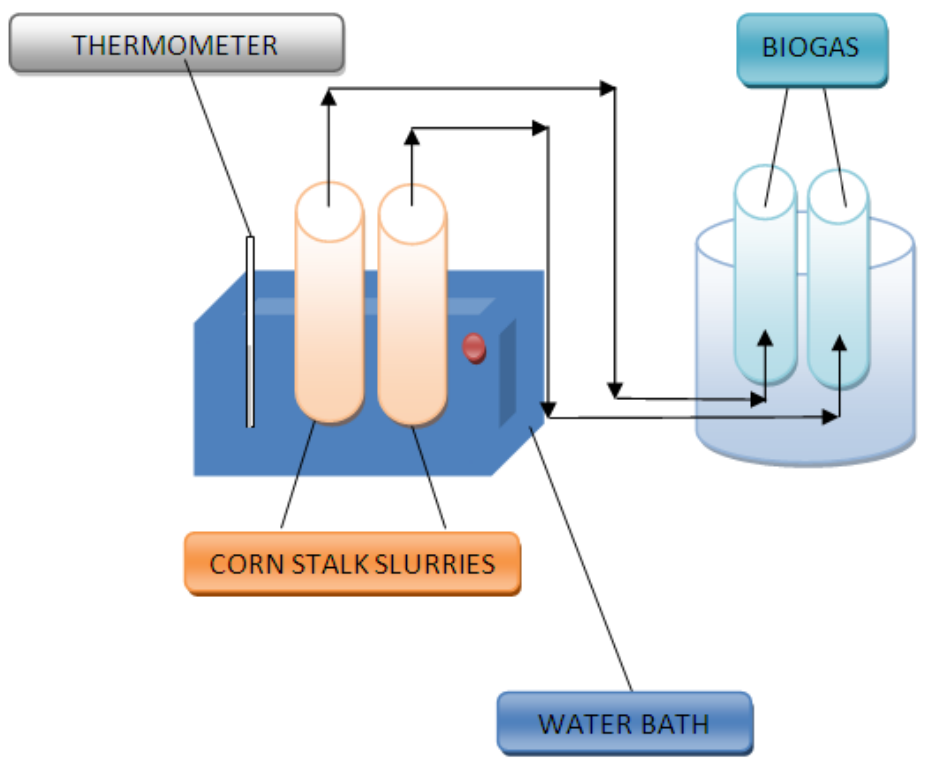

Figure 1. The biogas digester

\subsection{Biodegradation of Corn Stalks with the 3 Different Mesh Sizes}

Slurries containing $4.0 \mathrm{~g}$ crushed corn stalks with the particle diameters of $\leq 1.0 \mathrm{~mm}, \leq 2.0 \mathrm{~mm}$ and $\leq 3.0 \mathrm{~mm}$ were allowed to undergo biodegradation separately after the addition of $10 \mathrm{~cm}^{3}$ tap water i.e. $1: 2.5\left(\mathrm{~g} / \mathrm{cm}^{3}\right) \mathrm{ratio}$.

\subsection{Biodegradation with PDA(Potato Dextrose Agar)}

$0.1 \mathrm{~g}, 0.3 \mathrm{~g}, 0.5 \mathrm{~g}$, and $0.7 \mathrm{~g}$ PDA was each added separately to $4.0 \mathrm{~g}$ of crushed corn stalks. $10 \mathrm{~cm}^{3}$ of water was then added to each sample before biodegradation commenced.

\subsection{Biodegradation with Urea}

The slurries used were $4.0 \mathrm{~g}$ crushed corn stalks containing $10 \mathrm{~cm}^{3}$ water. Each was allowed to separately undergo biodegradation with $0.01 \mathrm{~g}, 0.05 \mathrm{~g}$ and $0.1 \mathrm{~g}$ of urea respectively.

\subsection{Biodegradation with PDA/Urea mixture}

$0.3 \mathrm{~g}$ PDA and $0.01 \mathrm{~g}$ urea were added to $4.0 \mathrm{~g}$ crushed corn stalks separately after which $20 \mathrm{~cm}^{3}$ of water was added to each sample. These mixtures were exposed for 24 hours and then allowed to undergo biodegradation.

\subsection{Addition of Nutrients at the termination of Biodegradation}

At the termination of biodegradation (after 7 days), $10 \mathrm{~cm}^{3}$ of water and $0.01 \mathrm{~g}$ of urea were added to the digester 
containing $4.0 \mathrm{~g}$ crushed corn stalks to determine the effect of the urea added on biogas production.

\section{Results}

Table 1. Volumes of biogas produced from $4.0 \mathrm{~g}$ crushed corn stalks with $\leq 1.0 \mathrm{~mm}, \leq 2.0 \mathrm{~mm}$ and $\leq 3.0 \mathrm{~mm}$ particle diameters

\begin{tabular}{cccc}
\hline \multirow{2}{*}{ Period (days) $)$} & \multicolumn{3}{c}{ Volumes of biogas produced $\left(\mathrm{cm}^{3}\right)$} \\
\cline { 2 - 4 } & $\leq 1.0 \mathrm{~mm}$ diameter & $\leq 2.0 \mathrm{~mm}$ diameter & $\leq 3.0 \mathrm{~mm}$ diameter \\
\hline 1 & - & - & - \\
$11 / 2$ & 6.4 & 4.1 & 3.2 \\
2 & 14.2 & 10.9 & 6.5 \\
3 & 10.2 & 4.8 & 3.1 \\
4 & 5.1 & 3.5 & 2.1 \\
5 & 4.8 & 1.5 & 1.0 \\
6 & - & - & - \\
7 & - & - & - \\
Total & 40.7 & 24.8 & 15.9 \\
\hline
\end{tabular}

Table 2. Volumes of biogas produced from $4.0 \mathrm{~g}$ corn stalks with $\leq 1.0 \mathrm{~mm}$ particle diameter after adding $0.1 \mathrm{~g}$, $0.3 \mathrm{~g}, 0.5 \mathrm{~g}$, and $0.7 \mathrm{~g}$ PDA

\begin{tabular}{ccccc}
\hline \multirow{2}{*}{ Period (days) } & \multicolumn{4}{c}{ Volumes of biogas produced $\left(\mathrm{cm}^{3}\right)$ after adding } \\
\cline { 2 - 5 } & $0.1 \mathrm{~g}$ PDA & $0.3 \mathrm{~g}$ PDA & $0.5 \mathrm{~g}$ PDA & $0.7 \mathrm{~g}$ PDA \\
\hline 1 & - & - & 13.1 & 5.4 \\
2 & 11.6 & 11.8 & 33.6 & 26.6 \\
3 & 32.6 & 33.1 & 10.5 & 14.2 \\
4 & 35.4 & 37.6 & 3.5 & 3.8 \\
5 & 7.5 & 8.3 & - & - \\
6 & 0.9 & 1.5 & - & - \\
7 & - & - & - & - \\
8 & - & - & - & - \\
Total & 88.0 & 92.3 & 60.7 & 50.0 \\
\hline
\end{tabular}

Table 3. Volumes of biogas produced from $4.0 \mathrm{~g}$ corn stalks with $\leq 1.0 \mathrm{~mm}$ particle diameter after adding $0.01 \mathrm{~g}$, $0.05 \mathrm{~g}$ and $0.1 \mathrm{~g}$ Urea

\begin{tabular}{cccc}
\hline \multirow{2}{*}{ Period (days) } & \multicolumn{3}{c}{ Volumes of biogas produced $\left(\mathrm{cm}^{3}\right)$ after adding } \\
\cline { 2 - 4 } & $0.01 \mathrm{~g}$ Urea & $0.05 \mathrm{~g}$ Urea & $0.1 \mathrm{~g}$ Urea \\
\hline 1 & - & - & - \\
$11 / 2$ & 15.3 & 8.8 & 2.1 \\
2 & 33.9 & 20.1 & 9.6 \\
3 & 25.5 & 15.5 & 7.9 \\
4 & - & - & 2.0 \\
5 & - & - & \\
6 & - & - & 1.8 \\
7 & - & - & 1.6 \\
8 & - & - & 1.2 \\
9 & - & - & - \\
Total & 74.7 & 44.4 & 26.2 \\
\hline
\end{tabular}


Table 4. Volumes of biogas produced from $4.0 \mathrm{~g}$ corn stalks with $\leq 1.0 \mathrm{~mm}$ particle diameter after adding $0.01 \mathrm{~g}$ urea and $0.3 \mathrm{~g}$ PDA

\begin{tabular}{cc}
\hline Period (days) & Volumes of biogas produced $\left(\mathrm{cm}^{3}\right)$ \\
\hline 1 & 11.4 \\
2 & 51.2 \\
3 & 30.8 \\
4 & 10.6 \\
5 & - \\
6 & - \\
Total & 104.0 \\
\hline
\end{tabular}

Table 5. Volumes of biogas produced from $4.0 \mathrm{~g}$ corn stalks with $\leq 1.0 \mathrm{~mm}$ particle diameter after adding $0.01 \mathrm{~g}$ urea at the termination of biodegradation

\begin{tabular}{cc}
\hline Period (days) & Volumes of biogas produced $\left(\mathrm{cm}^{3}\right)$ \\
\hline 1 & - \\
$1 \frac{1}{2}$ & 5.3 \\
2 & 14.9 \\
3 & 11.7 \\
4 & 5.8 \\
5 & 3.6 \\
6 & - \\
7 & - \\
\hline Total & - \\
8 & 5.2 \\
9 & 3.3 \\
10 & 0.1 \\
11 & - \\
12 & - \\
13 & 49.9 (after urea addition) \\
\hline Total &
\end{tabular}

\section{Discussion}

The generation of biogas from agricultural wastes produces an energy resource that can be effectively utilized. In Nigeria, the resources of agricultural wastes are very vast and as such, she has a very good potential for biogas production by anaerobic digestion.

\subsection{Effect of Corn Stalks Particle Diameter on Biogas Yield}

Table 1 shows the trend of biogas production. The highest biogas yield was obtained for $\leq 1.0 \mathrm{~mm}$ corn stalks particle diameter. $\leq 2.0 \mathrm{~mm}$ corn stalks particle diameter produced a high biogas yield while $\leq 3.0 \mathrm{~mm}$ particle diameter corn stalks produced the least biogas volume. Biogas yield was recorded after $1 \frac{1}{2}$ days. Since $\leq 1.0 \mathrm{~mm}$ particle diameter was the smallest mesh size used in this experiment, it means that the smaller the mesh size, the more the sites that are accessible for microorganism activity and biodegradation hence, the higher the biogas production.

\subsection{Effect of PDA on Biogas Yield}

When $0.1 \mathrm{~g}, 0.3 \mathrm{~g}, 0.5 \mathrm{~g}$, and $0.7 \mathrm{~g}$ PDA was each, added separately to $\leq 1.0 \mathrm{~mm}$ particle diameter size of $4.0 \mathrm{~g}$ corn stalks before biodegradation, biogas yields were enhanced tremendously (Table 2). However, $0.3 \mathrm{~g}$ PDA 
addition produced the highest biogas with yield decreasing with an increase in PDA concentration. $0.3 \mathrm{~g}$ PDA is probably the optimum PDA concentration for the biodegradation of $\leq 1.0 \mathrm{~mm}$ particle diameter size of $4.0 \mathrm{~g}$ corn stalks.

\subsection{Effect of Urea on Biogas Yield}

Table 3 shows an increase in biogas yield with the addition of $0.01 \mathrm{~g}, 0.05 \mathrm{~g}$ and $0.1 \mathrm{~g}$ urea. With the addition of $0.01 \mathrm{~g}$ and $0.05 \mathrm{~g}$ urea however, biodegradation lasted for only 3 days. When $0.1 \mathrm{~g}$ of urea was added, there was a decrease in biogas yield and a prolonged biodegradation period because the $0.1 \mathrm{~g}$ urea added was toxic to the microorganisms thereby inhibiting biodegradation. The higher the urea concentration, the lower the biogas yield.

\subsection{Effect of Urea and PDA Mixture on Biogas Yield}

A mixture of $0.3 \mathrm{~g}$ PDA and $0.01 \mathrm{~g}$ urea enhanced microorganism growth and activity thereby enhancing biogas yield (Table 4). Biogas production was recorded on the first day and lasted for only 4 days. The total biogas volume recorded in this experiment was higher than when only one of the nutrients was used. This is an indication that a mixture of small concentrations of PDA and urea is a better nutrient than either PDA or urea alone.

\subsection{Effect of Urea on Biogas Yield at the Termination of Biodegradation}

When biodegradation terminated (after 7 days), $0.01 \mathrm{~g}$ urea was added to the slurry, more biogas production was observed on the 9th, 10th and 11th days (Table 5). The added urea provided additional nutrient for microorganism growth and activity resulting in subsequent additional biodegradation and more biogas production.

\section{Conclusion}

Corn stalks are biomass that is biodegradable with mesophilic flora at $38{ }^{\circ} \mathrm{C}$. Particle diameter has a significant effect on biogas production. The smaller the particle diameter, the more the sites that are available for microorganism attack and biodegradation and hence, there is an increase in biogas production. Low concentrations of nutrients such as PDA and urea have enhancing effects on reaction time and biogas yield. However, these concentrations should be reduced to minimum values to avoid toxicity to microorganisms. The higher the concentrations of PDA and urea, the lower the biogas production. A mixture of PDA and urea is a better nutrient than PDA or urea alone. At the termination of biodegradation, the addition of low concentrations of urea aided the growth and activity of microorganisms which in turn enhanced the production of more biogas.

The methane contained in biogas can be upgraded to the same standards as fossil natural gas. This can be done by taking it through a cleaning process which involves the removal of carbon dioxide, water, hydrogen sulphide and other impurities. In order for it to attain pipeline quality and be accepted for local distribution network, the composition must be appropriate.

\section{References}

Ahring, B. K. (2003). Perspectives for anaerobic digestion. Advances In Biochemical Engineering/Biotechnology, 8, 1-30. http://dx.doi.org/10.1007/3-540-45839-5_1

Ajiboye, A. E. (1994). A Comparative Study of the biodegradation of lignocellulose from maize stalk and cob in biogas production (M.Sc dissertation, University of Jos, Nigeria).

Bhattacharya, S. C., Abdul-Salam, P., \& Sharma, M. (2000). Emissions from biomass energy use in some selected Asian countries. Energy, 25(2), 169-188. http://dx.doi.org/10.1016/S0360-5442(99)00065-1

Bhattacharya, S. C., Thomas, J. M., \& Abdul-Salam, P. (1997). Greenhouse gas emissions and the mitigation potential of using animal wastes in Asia. Energy, 22(11), 1079-1085. http://dx.doi.org/10.1016/S0360-5442(97)00039-X

Börjesson, P., \& Mattiasson, B. (2008). Biogas as a resource-efficient vehicle fuel. Trends in Biotechnol, 26(1), 7-13. http://dx.doi.org/10.1016/j.tibtech.2007.09.007

Jingura, M. R., \& Matengaifa, R. (2009). Optimization of biogas production by anaerobic digestion for sustainable energy development in Zimbabwe. Renewable and Sustainable Energy Reviews, 13(5), 1116-1120. http://dx.doi.org/10.1016/j.rser.2007.06.015

Klass, D. L. (1998). Biomass for renewable energy, fuels and chemicals. San Diego: Academic Press. http://dx.doi.org/10.1016/B978-012410950-6/50015-5

Klass, D. L. (2004). Biomass for Renewable Energy and Fuels. Encyclopedia of Energy, 2004, $193-212$. 
http://dx.doi.org/10.1016/B0-12-176480-X/00353-3

Li, J., Zhuang, D., De Laquil, P., \& Larson, E. D. (2001). Biomass energy in China and its potential. Energy for Sustainable Development, 5(4), 66-80. http://dx.doi.org/10.1016/S0973-0826(08)60286-0

Li, Z., Tang, R., Xia, C., Luo, H., \& Zhong, H. (2005). Towards green rural energy in Yunnan, China. Renew Energy Rev, 30(2), 99-108. http://dx.doi.org/10.1016/j.renene.2004.05.011

Pind, P. F., Angelidaki, I., \& Ahring, B. K. (2003). Dynamics of the anaerobic process: effects of volatile fatty acids. Biotechnology and Bioengineering, 82(7), 791-801. http://dx.doi.org/10.1002/bit.10628

Smith, K. (1994). Heat energy and greenhouse-gas impacts of biomass combustion in household stoves. Energy Sustain Dev, 1(4), 23-29. http://dx.doi.org/10.1016/S0973-0826(08)60067-8

Streets, D. G., \& Waldhoff, S. T. (1999). Greenhouse-gas emissions from biofuel combustion in Asia. Energy, 24(10), 841-855. http://dx.doi.org/10.1016/S0360- 5442(99)00030-4

Wang, X., \& Li, J. (2005). Influence of using household biogas digesters on household energy consumption in rural areas- a case study in Lianshui County in China. Renew Sustain Energy Rev, 9(2), 229-236. http://dx.doi.org/10.1016/j.rser.2004.04.004

Wang, X., Di, C., Hu, Z., Wu, W., Jiang, X., \& Jiang, S. (2007). The influence of using biogas digesters on family energy consumption and its economic benefit in rural areas-comparative study between Lianshui and Guichi in China. Renew Sustain Energy Rev, 11(5), 1018-1024. http://dx.doi.org/10.1016/j.rser.2005.08.001

Wyman, C. E., Decker, S. R., Himmel, M. E., Brady, J. W., Skopec, C. E., \& Viikari, L. (2005). Polysaccharides (2nd ed.). New York: Marcel Dekker.

Zeng, W., Ma, Y., \& Ma, L. (2007). Utilization of straw in biomass energy in China. Renew Sustain Energy Rev, 11(5), 976-987. http://dx.doi.org/10.1016/j.rser.2005.10.003

Zhang, P., Jia, G., \& Wang, G. (2007). Contribution to emission reduction of $\mathrm{CO}_{2}$ and $\mathrm{SO}_{2}$ by household biogas construction in rural China. Renew Sustain Energy Rev, 11(8), 1903-1912. http://dx.doi.org/10.1016/j.rser.2005.11.009

\section{Copyrights}

Copyright for this article is retained by the author(s), with first publication rights granted to the journal.

This is an open-access article distributed under the terms and conditions of the Creative Commons Attribution license (http://creativecommons.org/licenses/by/3.0/). 